\title{
FAKTOR-FAKTOR YANG BERHUBUNGAN DENGAN KEJADIAN DEMAM BERDARAH DENGUE DI KOTA BENGKULU
}

\author{
Hermansyah, Febryan Harya \\ Poltekkes Bengkulu, Jurusan Keperawatan Jl. Indragiri No.3 Bengkulu \\ Stikes Dehasen Bengkulu, Jl. Merapi Raya No. 42 Bengkulu
}

\begin{abstract}
Data of Bengkulu City Health Department show that in the last 5 years the number of dengue cases in the city of Bengkulu continues to increase. This study aims to determine the factors associated with the incidence of dengue hemorrhagic fever in the city of Bengkulu in 2012. The type of research used was the analytic case-control design. The populations in this study were all citizens of Bengkulu town. The total number of sample was 37 people for groups of cases and 37 people for the control group. The samples were taken by consecutive sampling technique. The data were collected with interview techniques and direct observation by using questionnaires. The data analysis was performed with univariate and bivariate analysis with Chi-Square test at $\alpha 5 \%$. The results showed that more than half of respondents $(54.1 \%)$ in the case and a minority of respondents $(27 \%)$ in the control group had lack knowledge level about the prevention of dengue disease, the majority of respondents $(80.1 \%)$ in the case and more than half of respondents $(56.8 \%)$ in the control group had a lack habit of implementing 3M's, more than half of respondents $(67.6 \%)$ and a minority of respondents $(37.8 \%)$ in the control group, it was found that they did not have quite fine environment. There was a significant association between knowledge about dengue prevention $(p=0.033)$, the habit of carrying out the movement of $3 \mathrm{M}(p=0.044$,$) and the condition of$ the home environment $(p=0.02)$ with the incidence of dengue in the city of Bengkulu in 2012. It is recommended to the Bengkulu City Health Department and health centers to further intensify do health promotion activities on dengue prevention in order to increase knowledge and awareness to maintain a healthy home environment, especially with the motion mosquito eradication nest (PSN).
\end{abstract}

Abstrak : Data dinas kesehatan Kota Bengkulu menunjukkan bahwa dalam 5 tahun terakhir terus terjadi peningkatan jumlah kasus DBD di Kota Bengkulu. Penelitian ini bertujuan mengetahui faktor-faktor yang berhubungan dengan kejadian demam berdarah dengue di Kota Bengkulu tahun 2012. Jenis penelitian ini adalah analitik dengan menggunakan rancangan case control. Populasi dalam penelitian ini adalah seluruh warga Kota Bengkulu, dengan jumlah sampel sebanyak 37 orang untuk kelompok kasus dan 37 orang untuk kelompok kontrol dan diambil dengan teknik consecutive sampling. Pengumpulan data dilakukan dengan teknik wawancara dan pengamatan secara langsung dengan menggunakan kuesioner. Analisis data dilakukan dengan analisis univariat dan bivariat dengan uji Chi-Square pada $\alpha 5 \%$. Hasil penelitian menunjukkan lebih dari setengah responden $(54,1 \%)$ pada kelompok kasus dan sebagian kecil responden $(27 \%)$ pada kelompok kontrol memiliki tingkat pengetahuan yang kurang tentang pencegahan penyakit DBD, sebagian besar responden $(80,1 \%)$ pada kelompok kasus dan lebih dari setengah responden $(56,8 \%)$ pada kelompok kontrol memiliki kebiasaan melaksanakan gerakan 3M yang kurang, lebih dari setengah responden $(67,6 \%)$ dan sebagian kecil responden $(37,8 \%)$ pada kelompok kontrol memiliki kondisi lingkungan rumah yang kurang baik. Ada hubungan yang bermakna antara pengetahuan tentang pencegahan DBD ( $\mathrm{p}=0,033)$, kebiasaan melaksanakan gerakan 3M ( $\mathrm{p}=0,044$,) dan kondisi lingkungan rumah $(\mathrm{p}=0,02)$ dengan kejadian DBD di Kota Bengkulu tahun 2012. Disarankan kepada pihak Dinas Kesehatan Kota Bengkulu dan Puskesmas untuk lebih mengintensifkan kegiatan promosi kesehatan tentang pencegahan DBD untuk meningkatkan pengetahuan dan kesadaran masyarakat untuk menjaga kesehatan lingkungan rumah terutama dengan melakukan gerakan pemberantasan sarang nyamuk (PSN).

Kata Kunci $\quad$ : DBD, Pengetahuan, 3M, Lingkungan Rumah.

Penyakit demam berdarah dengue (DBD) atau dengue hemorrhagic fever (DHF) merupakan penyakit menular yang sampai saat ini masih menjadi salah satu masalah kesehatan. Hampir di setiap tahun selalu terjadi peningkatan jumlah kasus serta daerah persebaran yang semakin meluas. Meskipun terjadi penurunan jumlah kematian secara nasional, di beberapa daerah 
angka kematian akibat DBD masih tetap tinggi (Depkes RI, 2008).

Penyakit yang ditularkan melelui gigitan nyamuk Aedes aegypti ini merupakan penyakit demam akut yang disebabkan oleh 4 serotipe virus Dengue dan ditandai dengan empat gejala klinis utama, yaitu demam yang tinggi, manifestasi perdarahan, hepatomegali, dan tanda-tanda kegagalan sirkulasi sampai timbulnya renjatan (syok) sebagai akibat dari kebocoran plasma yang dapat menyebabkan kematian (Soegijanto, 2002).

Sebagai negara dengan iklim tropis, Indonesia mempunyai resiko besar untuk terjangkit penyakit demam berdarah dengue karena virus Dengue dan nyamuk penularnya yaitu Aedes aegypti tersebar luas di seluruh daerah, kecuali daerah yang ketinggiannya lebih dari 1.000 meter dari permukaan air laut (Depkes RI, 2005). Hasil studi epidemiologik menunjukkan bahwa kejadian luar biasa (KLB) dengue biasanya terjadi di daerah endemis dan berkaitan dengan datangnya musim hujan, sehingga terjadi peningkatan aktifitas vektor dengue pada musim hujan yang dapat menyebabkan terjadinya penularan penyakit DBD pada manusia melalui gigitan nyamuk Aedes (Djunaedi, 2006).

Sekitar 2,5 - 3 miliar orang di seluruh dunia berisiko terkena penyakit ini. Berdasarkan hasil perkiraan di seluruh dunia setiap tahun sedikitnya terjadi 100 juta kasus DBD dengan 500 ribu kasus memerlukan rawat inap dan $90 \%$ diantaranya merupakan anak-anak yang berusia kurang dari 15 tahun. Case Fatality Rate (CFR) mencapai $5 \%$ dengan perkiraan 25 ribu kematian (WHO, 2004).

Penyakit ini di Indonesia pertama kali terjadi di Surabaya dan Jakarta pada tahun 1968 dan menyebar keseluruh provinsi pada tahun 1994. Sejak terjadi pertama kali pada tahun 1968 angka kesakitan kasus DBD di Indonesia terus meningkat. Tahun 1968 jumlah kasus DBD tercatat sebanyak 53 orang (Incidence Rate (IR) 0.05/100.000 penduduk, CFR 42,8\%). Meningkat menjadi 47.573 kasus dengan
1.527 kematian (IR 27,09/100.000 penduduk, CFR 3,2\%) pada tahun 1988 (Hadinegoro dan Satari, 2002).

Data Departemen Kesehatan menunjukkan setiap tahun selalu terjadi peningkatan kasus DBD secara nasional, meskipun terjadi kecenderungan penurunan jumlah kematian namun angka tersebut masih tetap tinggi. Tahun 2003 tercatat 51.516 kasus DBD (IR 23,87/100.000 penduduk, CFR 1,5\%), meningkat menjadi 79.462 kasus pada tahun 2004 (IR 37,11/100.000 penduduk, CFR 1,2\%). Tahun 2005 tercatat 95.279 kasus (IR 43,42/100.000 penduduk, CFR 1,36 \%), meningkat menjadi 114.656 kasus (IR 52,48/ 100.000 pendududk, CFR 1,04\%) pada tahun 2006 dan 158.115 kasus (IR 71,78/100.000 penduduk, CFR 1,01\%) pada tahun 2007 (Depkes RI, 2007).

Demam berdarah dengue merupakan penyakit yang di tularkan melalui gigitan nyamuk Aedes aegypti. Semakin tinggi aktifitas dan populasi nyamuk Aedes aegypti maka semakin tinggi resiko untuk terkena DBD. Tempat penampungan air yang jarang dibersihkan, tidak tersedianya tutup penampungan air, pakaian yang bergantungan, mobilitas yang tinggi, banyaknya tempat penampungan air alami, lingkungan dengan populasi yang padat, daya tahan tubuh yang lemah dan perilaku hidup yang sehat yang kurang akan semakin memperbesar risiko seseorang untuk terkena DBD (Sutaryo, 2005).

Menurut Goron dalam Marwan (2009), suatu penyakit dapat terjadi karena adanya ketidak seimbangan antara ketiga komponen, yaitu manusia (Host), penyebab (Agent) dan lingkungan (Environment). Perubahan salah satu komponen akan mengubah keseimbangan interaksi ketiga komponen yang akan mengakibatkan bertambah atau berkurangnya penyakit. Menurut teori ini, penyebab penyakit DBD adalah karena adanya peningkatan agent infeksius dalam hal ini virus Dengue atau karena adanya perubahan lingkungan yang menguntungkan penyebaran agent. 
Lingkungan merupakan faktor pendukung terbesar terjadi penyakit di suatu daerah. Kondisi lingkungan yang buruk akan sangat mendukung berkembangnya agent penyebab penyakit. Kebersihan lingkungan yang kurang serta pemukiman yang sangat padat akan mempermudah dan mempercepat penyebaran penyakit. Untuk penyakit DBD, kebersihan tempat penampungan air yang sering menjadi tempat perkembang biakan nyamuk Aedes aegypti yang menjadi vektor penyebar virus Dengue akan sangat berpengaruh pada penyebaran penyakit ini. Selain itu banyaknya genangan air pada musim hujan juga mempengaruhi kejadian DBD (Depkes RI, 2005).

Perilaku merupakan faktor terbesar kedua setelah lingkungan yang mempengaruhi kesehatan individu, kelompok, atau masyarakat. Dari pengalaman bertahuntahun pelaksanaan pendidikan prilaku kesehatan selalu terjadi hambatan dalam rangka pencapaian tujuannya, yakni mewujudkan perilaku hidup sehat bagi masyarakatnya. Dari penelitian-penelitian yang ada terungkap, meskipun kesadaran masyarakat sudah tinggi, praktek (practice) tentang kesehatan atau perilaku hidup sehat masyarakat masih rendah (Notoatmodjo, 2007).

Pemerintah melalui Kementerian Kesehatan telah mencanangkan berbagai program promosi kesehatan dalam upaya pencegahan penyakit DBD seperti gerakan serentak berantas sarang nyamuk melalui gerakan pemberantasan sarang nyamuk (PSN) dengan 3M Plus ( menguras, menutup tempat penampungan air dan mengubur barang-barang bekas serta menaburkan bubuk abate). Diharapakan melalui kegiatan yang melibatkan seluruh masyarakat ini dapat menekan penyebaran penyakit DBD yang akhirnya akan berdampak pada menurunnya kasus DBD (Depkes RI, 2006). Namun karena kurangnya perilaku hidup sehat masyarakat menyebabkan angka kejadian DBD tetap tinggi.

Penelitian yang dilakukan oleh Mahardika tentang hubungan perilaku hidup bersih dan sehat dengan kejadian demam berdarah dengue di Kabupaten Kendal ta- hun 2009 menunjukkan bahwa ada hubungan antara kebiasaan membersihkan tempat penampungan air $(\mathrm{p}=0,044)$, menutup tempat penampungan air $(\mathrm{p}=0,002)$, mengubur barang-barang bekas $(\mathrm{p}=0,014)$, menggantung pakaian $(\mathrm{p}=0,001)$ dan memakai lotion anti nyamuk $(\mathrm{p}=0,002)$ dengan kejadian demam berdarah dengue (PSIKM UNNES, 2010).

Hasil penelitian ini sejalan dengan penelitian yang dilakukan oleh Ekawati tentang faktor-faktor yang berhubungan dengan kejadian DBD di Kabupaten Pacitan pada tahun 2009. Hasil penelitian menunjukkan bahwa ada hubungan antara frekuensi pengurasan tempat penampungan air $(\mathrm{p}=0,027)$, keberadaan tutup tempat penampungan air $(\mathrm{p}=0,001)$, keberadaan jentik nyamuk pada tempat penampungan air ( $\mathrm{p}=0,001)$, kebiasaan menggantung pakaian $(\mathrm{p}=0,001)$ dan pengetahuan tentang penyakit DBD $(\mathrm{p}=0,030)$ dengan kejadian demam berdarah dengue (PSIKM UNNES, 2010).

Berdasarkan data yang peneliti peroleh dari Dinas Kesehatan Kota Bengkulu, menunjukkan bahwa dalam lima tahun terakhir Di Kota Bengkulu terus terjadi peningkatan kasus DBD. Pada tahun 2007 ditemukan 170 kasus dengan 4 kasus kematian, tahun 2008 ditemukan 181 kasus dengan 1 kematian (IR 46,6/100.000 penduduk, CFR 0,75\%), tahun 2009 ditemukan 234 kasus dengan 10 kasus kematian (IR 81,8/ 100.000 penduduk, CFR 4,31 \%), tahun 2010 ditemukan 352 kasus dengan 10 kematian (IR 110/100. 000 penduduk, CFR 2, $85 \%$ ) dan tahun 2011 ditemukan 403 kasus dengan 7 kematian (IR 129,8/100.000 penduduk, CFR 1,73\%) (Dinkes Kota Bengkulu, 2011).

Data awal yang peneliti dapatkan dari tim surveilans penyakit menular Dinas Kesehatan Kota Bengkulu, sampai dengan tanggal 26 Januari tahun 2012 telah di temukan 33 penderita DBD yang di Rawat di Rumah Sakit di Kota Bengkulu. Terjadi peningkatan jumlah kasus bila di bandingkan dengan bulan yang sama pada tahun 2011 dimana pada bulan Januari tahun 
2011 terjadi 23 kasus DBD (Dinkes Kota Bengkulu, 2012).

Tujuan penelitian ini adalah untuk mengetahui faktor-faktor apa saja yang berhubungan dengan kejadian demam berdarah dengue.

\section{BAHAN DAN CARA KERJA}

Penelitian ini adalah analitik dengan menggunakan rancangan case control. Populasi penelitian adalah adalah seluruh penduduk Kota Bengkulu. Sampel pada penelitian ini diambil dengan menggunakan teknik consecutive sampling. Besar sampel dalam penelitian ini dihitung menggunakan rumus berikut ini :

$$
n_{1}: n_{2}=\frac{\left(Z \alpha \sqrt{2 \cdot P \cdot Q}+Z \beta \sqrt{P_{1} \cdot Q_{1}+P_{2} \cdot Q_{2}}\right)^{2}}{\left(P_{1}-P_{2}\right)^{2}}
$$

Berdasarkan perhitungan rumus di atas, maka besar sampel minimal pada masing- masing kelompok kasus dan kontrol adalah 37 responden, sehingga total sampel pada penelitian ini adalah 74 responden. Sampel kasus pada penelitian ini adalah warga Kota Bengkulu yang di diagnosis DBD oleh dokter serta bertempat tinggal di Kota Bengkulu dengan jumlah 37 responden. Sampel kontrol pada penelitian ini adalah warga Kota Bengkulu yang tidak di diagnosis DBD yang dalam penelitian ini merupakan tetangga dari kelompok kasus dengan jumlah 37 responden.
Data penelitian ini menggunkan data primer diperoleh dari wawancara dengan responden mengenai pengetahuan responden tentang pencegahan DBD, kebiasaan responden melaksanakan gerakan $3 \mathrm{M}$ Plus dan kondisi rumah lingkungan rumah tempat tinggal responden.

Analisis yang dilakukan pada penelitian ini adalah analisis univariat, analisis bivariat dengan menggunakan uji chi square $\left(\mathrm{x}^{2}\right)$ pada $\alpha 5 \%$. Sedangkan untuk melihat keeratan hubungan kedua variabel, menggunakan nilai OR (Odd rasio).

\section{HASIL}

Hasil penelitian disajikan dalam analisis univariat dari setiap variabel independen dan dependen. Penyajian dilanjutkan dengan hasil analisis bivariat yang bertujuan untuk mengetahui hubungan antara variabel independen dengan variabel dependen.

\section{Analisis Univariat}

Analisis univariat dilakukan pada masing-masing variabel untuk menggambarkan distribusi frekuensi masing-masing variabel tersebut. Berdasarkan wawancara dan observasi terhadap pengetahuan responden tentang pencegahan penyakit DBD, kebiasaan melaksanakan gerakan 3M dan kondisi lingkungan rumah responden diperoleh data sebagai berikut :

Tabel 1. Distribusi Responden Berdasarkan Tingkat Pengetahuan Tentang Pencegahan Penyakit DBD di Kota Bengkulu Tahun 2012.

\begin{tabular}{ccccc}
\hline \multirow{2}{*}{ Pengetahuan } & \multicolumn{2}{c}{ Kelompok Kasus } & \multicolumn{2}{c}{ Kelompok Kontrol } \\
\cline { 2 - 5 } & $\begin{array}{c}\text { Frekuensi } \\
(\mathbf{n}=\mathbf{3 7})\end{array}$ & Persentase (\%) & $\begin{array}{c}\text { Frekuensi } \\
(\mathbf{n = 3 7 )}\end{array}$ & Persentase (\%) \\
\hline Kurang & 20 & 54,1 & 10 & 27 \\
Baik & 17 & 45,9 & 27 & 73 \\
\hline
\end{tabular}

Dari tabel 1. dapat dilihat bahwa lebih dari setengah responden $(54,1 \%)$ pada kelompok kasus memiliki tingkat pengetahuan yang kurang tentang pencegahan penyakit DBD. Sedangkan pada kelompok kontrol, hanya sebagian kecil responden (27\%) yang memiliki tingkat pengetahuan yang kurang tentang pencegahan penyakit DBD. 
Tabel 2. Distribusi Jawaban Responden Pada Variabel Tingkat Pengetahuan Tentang Pencegahan Penyakit DBD di Kota Bengkulu Tahun 2012.

\begin{tabular}{ccccc}
\hline \multirow{2}{*}{ Pertanyaan No } & \multicolumn{2}{c}{ Salah } & \multicolumn{2}{c}{ Benar } \\
\cline { 2 - 5 } Frekuensi & Persentase $(\%)$ & Frekuensi & Persentase $(\%)$ \\
\hline 1 & 37 & 50 & 37 & 50 \\
3 & 7 & 9,5 & 67 & 90,5 \\
4 & 1 & 1,4 & 73 & 98,6 \\
5 & 36 & 48,6 & 38 & 51,4 \\
6 & 24 & 32,4 & 50 & 98,6 \\
7 & 1 & 1,4 & 73 & 93,6 \\
8 & 5 & 6,8 & 69 & 25,7 \\
9 & 55 & 74,3 & 19 & 98,6 \\
10 & 1 & 1,4 & 73 & 100 \\
11 & 0 & 0 & 74 & 100 \\
12 & 0 & 0 & 74 & 100 \\
\hline
\end{tabular}

Pada tabel 2 dapat dilihat bahwa hampir sebagian besar responden $(74,3 \%)$ memilih jawaban yang salah pada item pertanyaan nomor delapan tentang cara pencegahan DBD yang paling efektif.

Tabel 3. Distribusi Responden Berdasarkan Kebiasaan Melaksanakan Gerakan 3M dan Kondisi Lingkungan Rumah di Kota Bengkulu Tahun 2012.

\begin{tabular}{lcccc}
\hline \multirow{2}{*}{ Variabel } & \multicolumn{2}{c}{ Kelompok Kasus } & \multicolumn{2}{c}{ Kelompok Kontrol } \\
\cline { 2 - 5 } & $\begin{array}{c}\text { Frekuensi } \\
(\mathbf{n = 3 7 )}\end{array}$ & Persentase (\%) & $\begin{array}{c}\text { Frekuensi } \\
(\mathbf{n = 3 7 )}\end{array}$ & Persentase (\%) \\
\hline Kebiasan 3M & & & & 56,8 \\
$\quad$ Kurang & 30 & 80,1 & 21 & 43,2 \\
Baik & 7 & 18,9 & & 37,8 \\
Kondisi Lingkungan & 25 & 67,6 & 14 & 62,2 \\
Kurang & 12 & 32,4 & 23 & \\
Baik & & & & \\
\hline
\end{tabular}

Berdasarkan tabel 3 dapat dilihat bahwa, sebagian besar responden $(80,1 \%)$ pada kelompok kasus memiliki kebiasaan melaksanakan gerakan $3 \mathrm{M}$ yang kurang. Sedangkan pada kelompok kontrol, lebih dari setengah responden $(56,8 \%)$ memiliki kebiasaan melaksanakan gerakan $3 \mathrm{M}$ yang kurang. Lebih dari setengah responden $(67,6 \%)$ pada kelompok kasus memiliki kondisi lingkungan rumah yang kurang baik. Sedangkan pada kelompok kontrol, hanya sebagian kecil responden $(37,8 \%)$ yang memiliki kondisi lingkungan rumah yang kurang baik.

\section{Analisis Bivariat}

Analisis bivariat dilakukan untuk melihat hubungan antara variabel bebas dan terikat. Analisis bivariat dilakukan de-ngan uji chi square $\left(\mathrm{x}^{2}\right)$, dengan derajat kemaknaan $(\alpha)$ 0,05 dan tingkat signifikan 95\%. Sedangkan untuk mengetahui besar faktor risiko digunakan uji Odd Ratio (OR). Berikut ini adalah hasil analisis data tersebut : 
Tabel 4. Hubungan Tingkat Pengetahuan Tentang Pencegahan Penyakit DBD Kebiasaan Melaksanakan Gerakan 3M dan Kondisi Lingkungan Rumah dengan Kejadian DBD di Kota Bengkulu Tahun 2012.

\begin{tabular}{|c|c|c|c|c|c|c|c|}
\hline \multirow[t]{3}{*}{ Variabel } & \multicolumn{4}{|c|}{ Kejadian DBD } & \multirow{3}{*}{$X^{2}$} & \multirow{3}{*}{$P$} & \multirow{3}{*}{ OR $95 \% \mathrm{CI}$} \\
\hline & \multicolumn{2}{|c|}{ DBD } & \multicolumn{2}{|c|}{ Tidak DBD } & & & \\
\hline & $\begin{array}{c}\text { Frekuensi } \\
(\mathbf{n}=\mathbf{3 7})\end{array}$ & $\begin{array}{c}\text { Persentase } \\
\%\end{array}$ & $\begin{array}{c}\text { Frekuensi } \\
(\mathbf{n}=37)\end{array}$ & $\begin{array}{c}\text { Persentase } \\
\%\end{array}$ & & & \\
\hline \multicolumn{8}{|l|}{ Pengetahuan } \\
\hline Kurang & 20 & 54,1 & 10 & 27 & 4,541 & 0,033 & $3,1(1,2-8,3)$ \\
\hline Baik & 17 & 45,9 & 27 & 73 & & & \\
\hline \multicolumn{8}{|l|}{ Kebiasaan 3M } \\
\hline Kurang & 30 & 80,1 & 21 & 56,8 & 4,038 & 0,044 & $3,2(1,1-9,3)$ \\
\hline Baik & 7 & 18,9 & 16 & 43,2 & & & \\
\hline \multirow{3}{*}{$\begin{array}{l}\text { Kondisi Lingkungan } \\
\text { Kurang } \\
\text { Baik }\end{array}$} & 25 & 67.6 & 14 & 37.8 & & & \\
\hline & 12 & 32,4 & 23 & 62,2 & 5,421 & 0,02 & $3,4(1,3-8,9)$ \\
\hline & & & & & & & \\
\hline
\end{tabular}

Hubungan Pengetahuan tentang pencegahan penyakit DBD dengan Kejadian DBD

Pada tabel 4. dapat dilihat bahwa dari 37 responden yang menderita DBD terdapat 20 orang responden $(54,1 \%)$ yang memiliki pengetahuan yang kurang tentang pencegahan DBD. Sedangkan dari 37 orang responden yang tidak menderita DBD, ada 10 orang responden $(27 \%)$ yang memiliki pengetahuan yang kurang tentang pencegahan DBD.

Hasil uji statistik diperoleh nilai $p=0,033(p<0,05)$, bahwa ada hubungan yang bermakna antara pengetahuan responden tentang pencegahan penyakit DBD dengan kejadian DBD. Dari hasil analisis keeratan hubungan dua variabel diperoleh nilai Odd Ratio (OR) $=3,1(95 \%$ CI : 1,2$8,3)$ yang berarti responden yang memiliki tingkat pengetahuan yang kurang tentang pencegahan DBD mempunyai resiko 3,1 kali untuk menderita DBD dibandingkan dengan responden yang memiliki tingkat pengetahuan yang baik tentang pencegahan DBD.

\section{Hubungan Kebiasaan Melaksanakan Gerakan 3M dengan Kejadian DBD}

Bahwa dari 37 responden yang menderita DBD terdapat 30 orang responden $(80,1 \%)$ yang memiliki kebiasaan melaksanakan gerakan $3 \mathrm{M}$ yang kurang. Sedangkan dari 37 orang responden yang tidak menderita DBD, ada 21 orang responden $(56,8 \%)$ yang memiliki kebiasaan melaksanakan gerakan 3M yang kurang.
Hasil uji statistik didapatkan nilai $p=0,044(p<0,05)$, bahwa ada hubungan yang bermakna antara kebiasaan melaksanakan gerakan 3M dengan kejadian DBD. Dari hasil uji statistik keeratan hubungan dua variabel diperoleh nilai $\mathrm{OR}=3,2(95 \%$ CI : 1,1-9,3), artinya responden yang memiliki kebiasaan melaksankan gerakan 3M yang kurang mempunyai resiko 3,2 kali untuk menderita DBD dibandingkan dengan responden yang memiliki kebiasaan melaksanakan gerakan 3M yang baik.

\section{Hubungan Kondisi Lingkungan Rumah dengan Kejadian DBD}

Bahwa dari 37 responden yang menderita DBD terdapat 25 orang responden $(67,6 \%)$ yang memiliki kondisi lingkungan rumah yang kurang baik. Sedangkan dari 37 orang responden yang tidak menderita DBD, ada 14 orang responden $(37,8 \%)$ yang memiliki yang memiliki kondisi lingkungan rumah yang kurang baik.

Hasil uji statistik diperoleh nilai $p=$ $0,02(p<0,05)$, bahwa ada hubungan yang bermakna antara kondisi lingkungan rumah responden dengan kejadian DBD di Kota Bengkulu. Dari hasil uji statistik keeratan hubungan dua variabel diperoleh nilai OR $=3,4(95 \% \mathrm{CI}: 1,3-8,9)$ yang berarti bahwa responden yang memiliki kondisi lingkungan rumah yang kurang baik mempunyai resiko 3,4 kali untuk menderita DBD dibandingkan dengan responden yang memiliki kondisi lingkungan rumah yang baik. 


\section{PEMBAHASAN}

\section{Hubungan Pengetahuan Tentang Pencega- han Penyakit DBD dengan Kejadian DBD}

Hasil penelitian ini menunjukkan bahwa $54,1 \%$ responden yang menderita DBD atau kelompok kasus memiliki tingkat pengetahuan yang kurang tentang pencegahan DBD, sisanya sebanyak $45,9 \%$ memiliki pengetahuan yang baik tentang pencegahan DBD. Sedangkan dari kelompok kontrol, hanya $27 \%$ responden yang memiliki pengetahuan yang kurang tentang pencegahan DBD, selebihnya sebanyak 73\% responden pada kelompok kontrol memiliki pengetahuan yang baik tentang pencegahan DBD. Hasil penelitian ini juga menunjukkan bahwa ada hubungan yang bermakna antara pengetahuan tentang pencegahan DBD dengan kejadian DBD di Kota Bengkulu $(p=0,033)$. Dari hasil penelitian juga diperoleh nilai Odd Ratio $(\mathrm{OR})=3,1(95 \% \mathrm{CI}: 1,2-8,3)$ yang berarti responden yang memiliki tingkat pengetahuan yang kurang tentang pencegahan DBD mempunyai resiko 3,1 kali untuk menderita DBD dibandingkan dengan responden yang memiliki tingkat pengetahuan yang tentang pencegahan DBD.

Hasil penelitian ini sejalan dengan hasil penelitian Ekawati (2009) tentang beberapa faktor yang berhubungan dengan kejadian DBD di Kabupaten Pacitan, yang menunjukan bahwa ada hubungan antara pengetahuan dengan kejadian DBD. Hasil penelitian tersebut menunjukkan bahwa dengan memiliki pengetahuan yang baik akan lebih memungkinkan seseorang untuk terhindar dari penyakit DBD.

Hasil penelitian ini juga sejalan dengan hasil penelitian Duma (2007) tentang analisis faktor yang berhubungan dengan kejadian DBD di Kecamatan Baruga Kota Kendari yang menyatakan bahwa ada hubungan antara faktor pengetahuan dengan kejadian DBD.

Pada penelitian ini adanya hubungan antara pengetahuan tentang pencegahan penyakit DBD dengan kejadian DBD dis- ebabkan karena lebih dari setengah responden yang menderita DBD memiliki tingkat pengetahuan tentang pencegahan penyakit DBD yang kurang. Hal ini sangat berbeda dengan responden yang tidak menderita DBD, hanya sebagian kecil saja yang memiliki tingkat pengetahuan tentang penyakit DBD yang kurang, sebagian besar resonden lainnya memiliki tingkat pengetahuan tentang pencegahan penyakit DBD yang baik. Hal ini bisa disebabkan karena masyarakat yang memiliki tingkat pengetahuan yang kurang tidak mengetahui penyebab dan sumber penularan penyakit DBD, sehingga mereka lebih berisiko untuk terkena DBD. Masih banyak masyarakat yang tidak tahu penyebab DBD, mereka beranggapan bahwa penyebab DBD adalah nyamuk, padahal nyamuk hanyalah fektor penyebar penyakit DBD. Penyebabnya sendiri adalah virus Dengue. Selain itu mereka juga tidak tahu cara mencegah penyakit DBD yang efektif. Selama ini terjadi kesalahan persepsi di masyarakat dimana masyarakat mengganggap bahwa fogging adalah cara yang paling efektif untuk mencegah dan memberantas DBD. Padahal fogging sangat tidak efektif karena hanya mebunuh nyamuk dewasa dan biayanya pun sangat mahal. Masyarakat juga lebih cenderung menunggu terjadinya penyakit dari pada proaktif untuk melakukan pencegahan.

Walaupun sebagian besar responden sudah mengetahui tentang gerakan $3 \mathrm{M}$ untuk mencegah penyakit DBD, tapi mereka justru tidak mau untuk melaksanakannya. Hal ini sudah sapatutnya jadi perhatian dari pihak terkait, terutama pihak Puskesmas dan pihak Dinas Kesehatan Kota Bengkulu untuk lebih proaktif mengajak masyarkat melakukan gerakan pencegahan DBD dari pada menunggu terjadinya penyakit. Selain itu pihak Puskesmas dan Dinas Kesehatan Kota Bengkulu juga harus meluruskan persepsi masyarakat yang tidak tepat tentang pelaksanan fogging selama ini, agar masyarkat tidak terus beranggapan bahwa fogging adalah satu-satunya cara untuk memberantas DBD. Selain mahal, fogging 
juga sangat tidak efektif untuk memberantas DBD. Selain itu, Puskesmas dan Dinas Kesehatan Kota Bengkulu juga harus terus melaksanakan penyuluhan tentang penyakit DBD dan cara pencegahannya untuk meningkatkan pengetahuan masyarkat. Dengan pengetahuan yang baik tentang DBD tentu akan mempengaruhi perilaku masyarakat dalam mencegah dan memberantas penyakit DBD karena pengalaman dan beberapa hasil penelitian juga telah membuktikan bahwa, perilaku yang didasari oleh pengetahuan akan lebih langgeng (menetap) dari pada perilaku yang tidak didasari oleh pegetahuan.

Menurut Notoatmodjo (2005), Pengetahuan atau kognitif merupakan domain yang sangat penting dalam membentuk tindakan seseorang (overt behaviort) Pengetahuan adalah merupakan hasil "tahu" dan ini terjadi setelah orang melakukan penginderaan terhadap suatu objek tertentu. Penginderaan terjadi melalui panca indra yakni: Indra penglihatan, pendengaran, penciuman, rasa dan raba. Sebagian besar pengetahuan manusia diperoleh melalui mata dan telinga. Menurut Sumantri (2000) pengertian pengetahuan adalah apa yang diketahui oleh manusia tentang objek tertentu, termasuk didalamnya tentang ilmu pengetahuan dapat diperoleh melalui berbagai cara baik melalui pengalaman atau proses belajar disekolah yang formal atau proses komunikasi baik secara langsung maupun tidak langsung.

Handoko (2000) mengatakan bahwa semakin baik pengetahuan seseorang, maka semakin baik pula perilaku seseorang terhadap kesehatannya dan sebaliknya jika pengetahuan tidak baik maka upaya perlindungan dirinya terhadap penyakit menjadi rendah.

\section{Hubungan Kebiasaan Melaksanakan Ge- rakan 3M dengan Kejadian DBD}

Hasil penelitian ini menunjukkan bahwa sebagian besar $(80,1 \%)$ responden yang menderita DBD memiliki kebiasaan melaksanakan gerakan 3M yang kurang, hanya $18,9 \%$ responden yang memiliki kebiasaan melaksankan gerakan 3M yang baik. Sedangkan dari kelompok kontrol, lebih dari setengah $(56,8 \%)$ responden memiliki kebiasaan melaksanakan gerakan 3M yang kurang juga. Sisanya, sebanyak $43,2 \%$ responden memiliki kebiasaan melaksananakan gerakan 3M yang baik. Hasil penelitian juga menunjukkan bahwa ada hubungan yang bermakna antara kebiasaan melaksanakan gerakan 3M dengan kejadian DBD di Kota Bengkulu $(p=0,044)$. Dari hasil penelitian juga diperoleh nilai $\mathrm{OR}=3,2(95 \% \mathrm{CI}: 1,1-9,3)$, yang berarti responden yang memiliki kebiasaan melaksankan gerakan 3M yang kurang mempunyai resiko 3,2 kali untuk menderita DBD dibandingkan dengan responden yang memiliki kebiasaan melaksanakan gerakan 3M yang baik.

Hasil penelitian ini sejalan dengan hasil penelitian yang dilakukan oleh Mahardika (2009) tentang hubungan perilaku kesehatan dengan kejadian DBD di Kabupaten Kendal. Hasilnya menunjukan bahwa ada hubungan antara kebiasaan membersihkan tempat penampungan air ( $p=$ $0,044)$, menutup tempat penampungan air $(p=0,002)$ dan mengubur barang-barang bekas $(p=0,014)$ dengan kejadian demam berdarah dengue.

Hasil penelitian ini juga sejalan dengan hasil penelitian Ekawati (2009) tentang beberapa faktor yang berhubungan dengan kejadian DBD di Kabupaten Pacitan, hasilnya menunjukkan bahwa ada hubungan antara frekuensi pengurasan tempat penampungan air $(p=0,027)$ dan keberadaan tutup tempat penampungan air $(p=0,001)$ dengan kejadian DBD.

Hasil penelitian ini juga didukung oleh hasil penelitian yang dilakukan oleh Arsin dan Wahiduddin (2004) di Makasar tentang faktor-faktor yang berpengaruh terhadap kejadian DBD yang menyimpulkan bahwa faktor yang paling berpengaruh terhadap kejadian DBD adalah kondisi fasilitas tempat penampungan air (TPA) yang kurang baik yang disebabkan karena pengurasannya yang lebih dari satu minggu 
sekali, tidak ditutup rapat dan terdapatnya jentik pada fasilitas TPA.

Duma (2007) yang melakukan penelitian tentang analisis faktor yang berhubungan dengan kejadian DBD di Kecamatan Baruga Kota Kendari menyatakan bahwa kondisi tempat penampungan air (TPA) berhubungan dengan kejadian DBD. Penelitian tersebut minyimpulkan bahwa faktor tempat penampungan air yang merupakan faktor paling berpengaruh dengan kejadian DBD.

Widyana (1998) yang melakukan penelitian tentang faktor-faktor risiko yang mempengaruhi kejadian DBD menyimpulkan bahwa kegiatan pemberantasan sarang nyamuk (PSN) dan gerakan 3M ditambahkan dengan cara menghindari kebiasaan menggantung pakaian di dalam kamar merupakan kegiatan yang mesti dilakukan untuk mengendalikan populasi nyamuk Aedes aegypti, sehingga penularan penyakit DBD dapat dicegah dan dikurangi.

Pada penelitian ini adanya hubungan antara kebiasaan melakukan gerakan $3 \mathrm{M}$ dengan kejadian DBD disebabkan karena sebagian besar responden yang menderita DBD memiliki kebiasaan melakukan gerakan 3M yang kurang. Meskipun lebih dari setengah responden pada kelompok kontrol juga memiliki kebiasaan melaksanakan gerakan 3M yang kurang, tapi persentase tersebut masih jauh lebih kecil jika dibandingkan dengan kebiasaan melakukan gerakan 3M yang kurang kelompok kasus. Responden yang memiliki kebiasaan melaksanakan gerakan 3M yang kurang mempunyai resiko besar untuk terkena DBD karena perilaku mereka tersebut sangat mendukung perkembangan nyamuk Aedes Aegyti sebagai vektor yang menyebarkan penyakit DBD.

Sumber penyebaran penyakit DBD adalah nyamuk Aedes Aegyti. Nyamuk Aedes Aegyti akan sangat cepat berkembang pada tempat-tempat penampungan air yang tidak berhubungan langsung dengan tanah apalagi jika tempat penampungan air tersebut jarang dibersihkan. Semakin banyak populasi nyamuk Aedes Aegyti akan semakin memperbesar resiko masyarakat untuk terkena DBD. Untuk memutuskan rantai penularan penyakit DBD sangat dibutuhkan peran dari pihak Dinas Kesehatan terutama Puskesmas di daerah atau kelurahan terkait untuk lebih mempromosikan serta mengajak masyarakat untuk melakukan gerakan 3M yang jika dilakukan dengan baik dan rutin akan sangat menekan perkembangan nyamuk Aedes Aegypti. Selain itu dengan melakukan gerakan $3 \mathrm{M}$ akan menciptakan lingkungan yang sehat. Dengan demikian masyarakat menjadi lebih mengetahui manfaat dari gerakan $3 \mathrm{M}$ dan mereka mau melaksanakannya sehingga perilaku hidup yang menyebabkan mudahnya mereka terinfeksi DBD lambat laun akan berubah.

Perilaku kesehatan pada dasarnya adalah suatu respon seorang (organisme) terhadap stimulus yang berkaitan dengan sakit dan penyakit, sistem pelayanan kesehatan, makanan serta lingkungan (Notoatmodjo, 2005). Batasan ini mempunyai dua unsur pokok yakni respon dan stimulus atau perangsangan. Respon atau reaksi manusia, baik bersifat pasif (pengetahuan, persepsi dan perilaku) maupun bersifat aktif (tindakan yang nyata atau praktek) sedangkan stimulus atau perangsangan disini terdiri 4 unsur pokok yakni sakit, penyakit, sistem pelayanan kesehatan dan lingkungan. Menurut Robert Kwick dalam Notoatmodjo (2005), perilaku adalah tindakan atau perbuatan suatu organisme yang dapat diamati dan bahkan dapat dipelajari. Faktor-faktor tersebut antara lain susunan syaraf pusat, persepsi, motivasi, emosi, proses belajar, lingkungan. Susunan syaraf pusat memegang peranan penting dalam perilaku manusia karena merupakan sebuah bentuk perpindahan dari rangsangan yang masuk menjadi perbuatan atau tindakan.

\section{Hubungan Kondisi Lingkungan Rumah de- ngan Kejadian DBD}

Hasil penelitian ini menunjukkan bahwa lebih dari setengah $(67,6 \%)$ responden pada kelompok kasus memiliki ling- 
kungan rumah yang kurang baik, hanya 12 $(32,4 \%)$ responden yang memiliki lingkungan rumah yang baik. Sedangkan pada kelompok kontrol, hampir sebagian responden $(37,8 \%)$ memiliki lingkungan rumah yang kurang baik. Sisanya lebih dari setengah responden $(62,2 \%)$ memiliki lingkungan rumah yang baik. Hasil penelitian juga menunjukkan bahwa ada hubungan yang bermakna antara kondisi lingkungan rumah dengan kejadian DBD di Kota Bengkulu $(p=0,02)$. Dari hasil penelitain juga diperoleh nilai OR $=3,4(95 \%$ $\mathrm{CI}: 1,3-8,9)$, yang berarti responden yang memiliki kondisi lingkungan rumah yang kurang baik mempunyai resiko 3,4 kali untuk menderita DBD dibandingkan dengan responden yang memiliki kondisi lingkungan rumah yang baik.

Hasil penelitian ini sejalan dengan hasil penelitian yang dilakukan Arsin dan Wahiduddin (2004) yang dilakukan di Makasar tentang faktor-faktor yang berpengaruh terhadap kejadian DBD, peneliti menyimpulkan bahwa kejadian DBD berhubungan dengan keadaan lingkungan dan kualitas pemukiman. Hasil penelitian ini juga sejalan dengan hasil penelitian yang dilakukan oleh Nugroho (1999) tentang faktor-faktor yang mempengaruhi penyebaran virus dengue. Penelitian tersebut menyimpulkan bahwa ada hubungan kepadatan rumah dengan penyebaran virus dengue.

Hasil penelitian ini juga sesuai dengan pendapat Depkes RI (2005) yang menyatakan bahwa keadaan pemukiman yang tidak memenuhi syarat kesehatan memberikan pengaruh yang signifikan terhadap adanya sarang nyamuk menularkan penyakit DBD.

Pada penelitian ini adanya hubungan antara kondisi lingkungan rumah dengan kejadian DBD disebabkan lebih dari setengah responden pada kelompok kasus memiliki kondisi lingkungan rumah yang kurang. Sedangkan pada kelompok kontrol, hanya sebagian kecil saja responden yang memiliki kondisi lingkungan rumah yang kurang. Sebagian besar kondisi lingkungan rumah responden yang masuk dalam kategori kurang dikarenakan rumah tersebut berada dilingkungan yang padat, kemudian banyak terdapat tempat penampungan air, baik bak mandi atau ember, pas bunga yang menggunakan air, tempat minum hewan peliharaan serta banyaknya pakaian yang bergantungan diluar lemari.

Lingkungan rumah yang padat erat kaitannya dengan penyebaran virus dengue dan jarak terbang nyamuk Aedes aegypti. Nyamuk Aedes aegypti merupakan nyamuk yang jarak terbangnya pendek (100 meter). Oleh karena itu nyamuk tersebut bersifat domestik. Apabila rumah penduduk saling berdekatan maka nyamuk dapat dengan mudah berpindah dari satu rumah ke rumah lainnya. Apabila penghuni salah satu rumah ada yang terinfeksi virus dengue, maka virus tersebut dapat ditularkan kepada tetangganya. Pada penelitian ini juga menunjukkan bahwa ada kecenderungan jarak antara rumah penderita DBD saling berdekatan atau berada dalam satu lingkungan dengan jarak antara 100-200 meter.

Kemudian, keberadaan tempat penampungan air seperti bak mandi, tempat penampungan air dari ember, pas bunga yang menggunakan air dan tempat minum hewan peliharaan erat kaitanya dengan perkembangan nyamuk Aedes aegypti. Apalagi jika tempat-tempat tersebut jarang dikuras dan dibersihkan, akan semakin potensial untuk menjadi tempat perkembang biakkan nyamuk Aedes aegyti. Dengan semakin tingginya populasi Aedes aegyti maka semakin besar risiko masyarakat untuk terkena DBD.

Sedangkan pakaian yang bergantungan didalam rumah atau kamar akan menjadi tempat potensial untuk nyamuk beristirahat sebelum berkembang biak atau bertelur. Nyamuk Aedes aegypti senang hinggap dan beristirahat di tempat-tempat gelap dan kain yang tergantung di dalam rumah seperti gorden, kelambu dan pakaian. Maka dari itu pakaian yang tergantung di balik pintu sebaiknya dilipat dan disimpan dalam almari, karena nyamuk Aedes aegypti se- 
nang hinggap dan beristirahat di tempattempat gelap dan kain yang tergantung untuk berkembang biak, sehingga nyamuk berpotensi untuk bisa mengigit manusia yang ada didalam rumah tersebut.

Kondisi lingkungan rumah merupakan salah satu faktor yang mempengaruhi kesehatan, baik kesehatan individu maupun kesehatan masyarakat. Menurut Blum dalam Wicaksono (2009), faktor-faktor yang mempengaruhi derajat kesehatan masyarakat meliputi keturunan, lingkungan, perilaku dan pelayanan kesehatan. Status kesehatan akan tercapai secara optimal bila keempat faktor tersebut bersama-sama mempunyai kondisi yang optimal pula.

Akan sangat sulit untuk merubah kondisi lingkungan, apalagi jika lingkungan tersebut sangat padat. Menjadi hal yang tidak mungkin jika harus memindahkan penduduk di lingkungan tersebut, yang dapat dilakukan hanyalah memodifikasi kondisi lingkungan tersebut sekaligus mengajak masyarakat untuk hidup sehat dan menjaga kebersihan lingkungan. Masyarakat juga harus rutin membersihkan tempat penampungan air serta mengurangi kebiasaan untuk menggantung pakaian di luar lemari agar dapat mengurangi populasi dan penyebaran nyamuk Aedes aegypti.

Menurut Goron dalam Marwan (2009), penyakit dapat terjadi karena adanya ketidak seimbangan antara ketiga komponen, yaitu manusia (Host), penyebab (Agent) dan lingkungan (Environment). Model penyebaran penyakit seperti ini di kenal dengan model segitiga epidemiologi (The Epidemiological Triangel). Perubahan salah satu komponen akan

\section{DAFTAR KEPUSTAKAAN}

Arsin AA dan Wahiduddin. 2004. Faktor-faktor yang Berpengaruh Terhadap Kejadian Demam Berdarah Dengue Di Kota Makasar.

Jurnal Kedokteran Yarsi. ISSN: 0854-1159 Vol. 12 No. 2. Mei-Agustus 2004: 23.

Depkes RI. 2005. Pencegahan dan Pemberantasan Demam Berdarah Dengue Di Indonesia. Jakarta: Depkes RI. .2008. Profil Kesehatan Indonesia 2007. Jakarta: Depkes RI (online, mengubah keseimbangan interaksi ketiga komponen yang akan mengakibatkan bertambah atau berkurangnya penyakit. Menurut model ini, penyebab sakit adalah karena adanya peningkatam agent infeksius atau karena adanya perubahan lingkungan yang menguntungkan penyebaran agent.

\section{KESIMPULAN}

Ada hubungan yang bermakna antara pengetahuan responden tentang pencegahan penyakit DBD dengan kejadian DBD di Kota Bengkulu ( $p=0,033)$. Ada hubungan yang bermakna antara kebiasaan melaksanakan gerakan 3M dengan kejadian DBD di Kota Bengkulu ( $p=0,044)$. Ada hubungan yang bermakna antara kondisi lingkungan rumah dengan kejadian DBD di Kota Bengkulu $(p=0,02)$.

Disarankan kepada pihak Dinas Kesehatan Kota Bengkulu dan Puskesmas terkait untuk lebih mengintensifkan kegiatan promosi tentang pencegahan DBD. Selain itu diharapakan kepada pihak Dinas Kesehatan Kota Bengkulu dan Puskesmas terkait untuk meluruskan anggapan masyarakat bahwa fogging adalah cara yang paling efektif dan baik untuk memberantas DBD karena anggapan tersebut tidak tepat. Selain tidak efektif karena hanya membunuh nyamuk Aedes aegypti dewasa saja, fogging juga dalam setiap pelaksanaanya membutuhkan biaya yang besar. Masyarakat juga sebaiknya lebih aktif melaksanakan gerakan pemberantasan sarang nyamuk (PSN) karena gerakan ini sangat efektif untuk mencegah DBD.

http://www.depkes.go.id , di akses 12 Desember 2011 ).

. 2009. Profil Kesehatan Indonesia 2008. Jakarta: Depkes RI (online, http://www.depkes.go.id , di akses 12 Desember 2011 ).

Dinas Kesehatan Kota Bengkulu. 2010. Profil Kesehatan Kota Bengkulu Tahun 2009. Bengkulu. Dinas kesehatan Kota Bengkulu. 
2011. Profil Kesehatan Kota Bengkulu Tahun 2010. Bengkulu. Dinas Kesehatan Kota Bengkulu.

Djunaedi D. 2006. Demam Berdarah [Dengue DBD] Epidemiologi, Imunopatologi, Patogenesis, Diagnosis dan Penatalaksanaannya. Malang: UMM Press.

Duma N., Darmawansyah, Arsin AA. 2007. Analisis Faktor Yang Berhubungan Dengan Kejadian Demam Berdarah Dengue Di Kecamatan Baruga Kota Kendari 2007. Vol. 4 No. 2. September 2007: 91-100.

Hadinegoro S., Soegijanto S., Wuryadi S., Seroso T. 2001. Tatalaksana Demam Berdarah Dengue Di Indonesia. Jakarta: Depkes RI (online, http://www.depkes.go.id, di akses 12 Desember 2011 ).

Hadinegoro dan Satari. 2002. Demam Berdarah Dengue Naskah Lengkap Pelatihan bagi Pelatih Dokter Spesialis Anak \& Dokter Spesialis Penyakit Dalam dalam Tatalaksana Kasus DBD. Jakarta: FK UI.

Kandun I. (ed.). 2000. Manual Pemberantasan Penyakit Menular. Jakarta: Infomedika.

Kristina, Isminah, Wulandari L. 2004. Kajian Masalah Kesehatan Demam Berdarah Dengue.( online, http://www.litbang.depkes.go.id., di akses 12 Desember 2012).

Marwan. 2009. Faktor-faktor yang Berhubungan dengan Kejadian Infeksi Cacing Usus Pada Murid MIN Bandar X Sunur Kecamatan Nan Sabaris Padang Pariaman Tahun 2009 (skripsi). Padang : PSIKM UNAND.

Nadezul, H. 2007. Cara Mudah Mengalahkan Demam Berdarah. Jakarta: Penerbit Buku Kompas
Notoatmodjo, S. 2003. Ilmu Kesehatan Masyarakat Prinsip-Prinsip Dasar. Jakarta: Rineka Cipta. .2005. Kesehatan Masyarakat Ilmu dan Seni. Jakarta: Rineka Cipta. ,2003. Metodelogi Penelitian Kesehatan. Jakarta: Rineka Cipta. .2007. Promosi Kesehatan dan Ilmu Perilaku. Jakarta: Rineka Cipta.

Sudigdo S, Sofyan I. 2002. Dasar-Dasar Metodelogi Penelitian Klinis. Jakarta : Binarupa Aksara.

Sumekar DW. 2007. Faktor-Faktor yang Berhubungan dengan Keberadaan Jentik Nyamuk Aedes di Kelurahan RajaBasa. Seminar Hasil Penelitian dan Pengabdian kepada Masyarakat. Bandar Lampung : UNILA.

Satari HI dan Meiliasari M. 2004. Demam Berdarah. Jakarta: Puspa Swara.

Wahyu M. 2009. Hubungan Perilaku Hidup Bersih dan Sehat dengan Kejadia DBD di Kabupaten Kendal tahun 2009 (skripsi). Semarang : PSIKM UNNES.

Widoyono. 2008. Penyakit Tropis : Epidemiologi, Penularan, Pencegahan dan Pemberantasannya. Jakarta. Penerbit Erlangga.

Widya E. 2009. Faktor-faktor yang Berhubungan dengan Kejadian DBD di Kabupaten Pacitan tahun 2009 (skripsi). Semarang : PSIKM UNNES.

Widyastuti P. (ed). 2005. Epidemiologi Suatu Pengantar, edisi 2. Jakarta: EGC.

WHO. 2004. Demam Berdarah Dengue : Pencegahan dan Penatalaksanaan. Jakarta : EGC.

Yatim, Faisal. 2007. Macam-Macam Penyakit Menular dan Cara Pencegahannya. Jilid 2. Jakarta: Pustaka Obor Populer. 